\title{
Collaborative research to enhance a business tourism destination: a case study from Porto
}

Jorge Marques \& Micaela Pinho

To cite this article: Jorge Marques \& Micaela Pinho (2020): Collaborative research to enhance a business tourism destination: a case study from Porto, Journal of Policy Research in Tourism, Leisure and Events, DOI: 10.1080/19407963.2020.1756307

To link to this article: https://doi.org/10.1080/19407963.2020.1756307 


\title{
Collaborative research to enhance a business tourism destination: a case study from Porto
}

\author{
Jorge Marques ${ }^{a, b}$ and Micaela Pinho $0^{a, c, d}$ \\ ${ }^{a}$ Research on Economics, Management and Information Technologies (REMIT), Univ. Portucalense, Porto, \\ Portugal $;{ }^{b}$ Centre of Studies on Geography and Spatial Planning (CEGOT), University of Coimbra, Coimbra, \\ Portugal; ${ }^{C}$ Portucalense Institute for Legal Research (IJP), Porto, Portugal; ${ }^{\circledR}$ Research Unit in Governance, \\ Competitiveness and Public Policies (GOVCOPP), University of Aveiro, Aveiro, Portugal
}

\begin{abstract}
The purpose of this study is to diagnose the business tourism segment in the city of Porto and to propose a set of strategic measures to boost its development and convert the territory into a preferred business tourism destination. The opinions of 28 local stakeholders were collected through a Delphi technique. Results show that experts consider business tourism very important for Porto, as they see it as a (i) strategic tourist product, (ii) complimentary product for leisure tourism and (iii) facilitator of entrepreneurship and business network and a booster of local and regional economy. A number of improvements were proposed to help build the brand of Porto as a business tourism destination of note: (i) more offer of large venues, (ii) collaborative cooperation between businesses to consolidate the sector, (iii) increase the supply of animation, (iv) a strong marketing strategy and building a cohesive brand and ( $v$ ) increase accessibilities, connectivity and facilities. Findings have important policy implications for Porto's policymakers in understanding market dynamics and planning their business tourism strategies. Moreover, findings have a broader interest as they off er constructive insights into strategies to develop business tourism worldwide and thus provide important implications for managers, policymakers and service providers.
\end{abstract}

ARTICLE HISTORY

Received 19 June 2019

Accepted 13 April 2020

\section{KEYWORDS}

Business tourism; business

events; destination attractiveness; strategic management; development policies; Delphi technique

\section{Introduction}

Business tourism is widely recognized as an important economic activity. The development of business tourism owes much to globalization. Globalization developed new forms of work, increasing the need for commercial, industrial and knowledge expansion and, as such, is a natural promoter of business travel and professional events. As business opportunities continue to expand worldwide, international business travel also increase (Cazanova et al., 2014; Gustafson, 2012; Lichy \& McLeay, 2018; Wang \& Beise-Zee, 2013) contributing to the promotion of countries' local, regional and national economies. Low seasonality, controlled environmental impact, higher revenue for accommodation 

and meeting venues, high demand for food and beverage, boost in leisure activities and the relative resilience to economic crisis are some main factors that make business events, in general, and business tourism, in particular, so attractive to destinations (Alananzeh et al., 2019; Jones \& Li, 2015; Millán et al., 2016; Rogerson, 2015a, 2015b). In 2018, business travel spending generated $22.5 \%$ of direct travel and tourism gross domestic product worldwide (WTTC, 2018), being expected to growth $3.1 \%$, annually, until 2030 (UNWTO, 2011). Business tourism plays an important role in tourism-led economic growth (Tan \& Tsui, 2017; Tsui et al., 2018). Besides direct revenue impact resulting from the tourist activity itself (e.g. accommodation, transport), business tourism has a direct connection with leisure tourism. It is often found that the length of stay at destination is extended beyond the business event or professional requirements so that visitors can know the region and its attractions. Therefore, the possibility of returning in leisure context or even the word-of-mouth promotion reflects the potential of business events for local and/or regional development (Tan \& Tsui, 2017; Tsui et al., 2018). Holding business events, especially large ones, plays a crucial role in the international projection of the country and contributes to enhancing the territory as a reference destination (Colombo \& Marques, 2019; Draper et al., 2018; Huang, 2016; Skinner, 2017). According to Getz and Page (2016), events, in general, are important for the promotion of a positive destination image, place marketing and co-branding with destination. This reflects the potential of business tourism for local and regional development and the importance of providing an excellent service to visitors to ensure high levels of satisfaction. High levels of satisfaction usually means very positive destination image and brand perceptions (Ahn, Kim, et al., 2016) and higher possibility of visitor's return, either for business purposes or leisure motivations. In this context, destination management organizations (DMO) and, more specifically, conventions \& visitors bureaux (CVB) play a key role in the supply side through marketing, management, planning and development of tourism destinations. CVB are central to structuring, promoting and projecting territories as business tourism destinations and prospecting and capturing events and visitors (Lee et al., 2016). Always acting in accordance with the regional interest, CVB use the perspective of diff erent agents that comprise the organizational structure, to make the destinations more sophisticated and enrich visitor's experience outside the business events (Bornhorst et al., 2010; Lee et al., 2016).

In Portugal, some strategies for business tourism development have been presented through the National Strategic Plan for Tourism (PENT, 2007) and, more recently, through the Tourism Strategy 2027 (ET, 2017). Both documents highlight the need to qualify infrastructures and equipment, reinforce the proactive capture of events and the creative development of supplies that contribute to provide memorable experiences to the participants.

Business tourism is a fast growing lucrative market segment. In 2018, 12,937 associative meetings were conducted worldwide representing near 4.9 million business tourists travelling around the globe just to participate in this specific type of business event (ICCA, 2019). Portugal is well positioned regarding value, individuality and a mid-range capacity for conferences and events. Relevant business events have been taken place in Portugal, such as the International Rotary Convention, in 2013, which included around 30,000 participants and the Web Summit held since 2016 and that will remain until 2028 involving around 70,000 participants. In 2018, Portugal hosted 308 meetings accounting for about 
113,000 participants and reached around 68 million euros with registration fees (ICCA, 2019). These numbers reflect the important economic impact of the business events. Portugal reached the world's top 11 and Europe's top 6 of the most popular destinations for international events. Lisbon dominates as a location, reaching an impressive 6th position in the worldwide cities context upon receiving 152 meetings (ICCA, 2019). Porto, the second largest Portuguese city, reached the 22nd position by hosting 71 meetings (ICCA, 2019).

The case study reported in this paper intends to investigate the potential to attract additional business tourism to Porto city, Portugal. Porto is strategically located in the northern of Portugal along the Douro River estuary with easy access by air route to the world through the airport located a short distance from the city, and road and train links from Lisbon. Porto is the only Portuguese city, besides Lisbon, recognized as a gamma-level global city by the Globalization and World Cities Study Group (GWCRN, 2018). Porto highlights a large variety of strengths including a dynamic business environment, proximity to the Spanish territory of Galicia, favourable airport location, important scientific research and technological development units, interesting and diff erent tourist attractions and activities to enhance business tourism packages, strong reputation as a leisure tourist destination, price competitiveness and friendly people. There is a good off er of accommodations in the 4 star (twenty-four 4 star hotels comprising 2591 rooms) and 5 star hotels (seven 5 star hotels comprising 1305 rooms). Porto has the added advantage of having a reference conference and event venue - Alfândegado Porto Congress Centre, recognized nationally and internationally with the awarding of several prizes (Europe's Best Meetings \& Conference Centre in 2014 and 2015 by the Business Destinations; Best Congress Space in 2013 and 2014 by the Publituris Portugal Travel Awards; Best Congress Centre in 2006, 2011-2013 and 2015 by the Gala de Eventos/ExpoEventos; Best National Supplier by the International Association of Professional Congress Organizers). This venue has $10,000 \mathrm{~m}^{2}$ available for exhibitions, reached a capacity for congresses up to 3000 people, for dinners up to 1700 people and up to 12,000 people for concerts. In addition, the old venue Rosa Mota Pavilion (also known as Crystal Palace) was finally renewed and was recently inaugurated under a new name - Super Bock Arena - Rosa Mota Pavilion. This venue has now a capacity to host business events up to 8000 people and is seen as a new strategic venue to increase the city competitiveness as a business tourism destination. Besides venue capacity, it is our belief that other strategic approaches could be followed to attract additional business events to Porto. Thus, in a context of day-to-day tourism planning decisions, we aim to investigate the opinions of key stakeholders in the sector about: (i) the diagnosis they make of the business tourism segment in Porto and (ii) their recommendations to boost its development in the territory.

\section{Literature review}

\section{Conceptual approach}

In 1991, touristic travel motivated by businesses and professional purposes, in the sphere of tourism, was recognized. The category of 'business and professional' was established to classify tourism trips according to the travel proposes, safeguarding that the main reason 
of the visit should exclude the exercise of a remunerated activity in the place visited. This idea does not seem, however, to be consensual. To some academics (e.g. Boniface \& Cooper, 2005; Lage \& Milone, 2000), business travel even implying remuneration reflects the use of the same services and facilities and, as such, should be enclosed in the overall concept of tourism. Moreover, business tourism can be converted into leisure tourism whenever the stay extends beyond the professional obligations. According to Beni (2001), business tourism comprises executives and businessmen travelling, flowing to big business and cosmopolitan centres to develop professional, commercial and industrial activities, employing their free time in local recreation activities and entertainment, including attendance at local restaurants.

Since business tourism is a specific sector characterized by fragmentation and heterogeneity (Abulibdeh \& Zaidan, 2017) some authors have classified this tourism segment according to diff erent strands of analysis, activities or events. For Davidson and Cope (2003), business travel can be grouped into 'individual business travel' or 'business tourism'. Individual business travel includes regular and necessary base trips so that an individual can perform the tasks or activities inherent to his or her profession, i.e. travel to the place where a problem has to be solved (e.g. a computer engineer who travels to solve a problem at a branch of the main company). These travels are 'non-discretionary' since the travel destination is not chosen but rather imposed. Business tourism includes meetings, exhibitions, incentive trips and corporate hospitality. The choices of the venues for such events are often flexible and associated with group travel (e.g. a group of university teachers travelling to attend a conference). Since there is the option to choose the destination, this business tourism segment is said to be 'discretionary'. This dichotomy between discretionary and non-discretionary was explored elsewhere (Davidson, 2019; Davidson \& Cope, 2003; Ho \& McKercher, 2014; Swarbrooke \& Horner, 2001). Rogers (2008) does not distinguish the concepts of individual business and business tourism. Business tourism is seen as a sub sector of global tourism that includes conferences, exhibitions and fairs, incentive travel, business events or hospitality as well as individual business trips. Nevertheless, the author recognized that conferences, exhibitions, incentive trips and corporate events or hospitality are the four main lines of business tourism that deserve special attention from the destinations and venues, once the events site may rotate and therefore be an important determinant in the destination choice. Another definition of business tourism, based on the 'formality', was explored by Rogerson (2015a, 2015b). According to the author, business tourism mobility can be formal (domestic and international) or informal (domestic and international) depending on whether business travellers will attend an organized event (formal) or not (informal). One of the main diffi culties in conceptualizing business tourism is the broad range of business events that can be identified (Swarbrooke \& Horner, 2001). This sector is usually defined either as independent business trips (e.g. non-discretionary, informal, individual travel) or travelling for purposes related to the participation on organized events such as meetings, incentives, exhibitions and conventions on the other (e.g. MICE tourism, discretionary, formal) (Davidson, 2019; Rogerson, 2015a, 2015b).

Although there's a lack of literature on business tourism, recent years have been fruitful in the emergence of studies embracing interconnected perspectives and diff erent areas of knowledge: geography and comparative studies (Abulibdeh \& Zaidan, 2017; Ho \& McKercher, 2014; Iacuone \& Zarrilli, 2018; Rogerson, 2015a, 2015b); economic analysis 
(Falk \& Hagsten, 2018; Jones \& Li, 2015; Tsui et al., 2018); sustainability (Mair \& Jago, 2010; Rittichainuwat \& Mair, 2012; Werner et al., 2017); attendees behaviours and motivations (Colombo \& Marques, 2019; Crouch \& Louviere, 2004; Lichy \& McLeay, 2018; Millán et al., 2016); destination planning and management policies (Alananzeh et al., 2019; Almeida-García, 2018; Carvalho et al., 2018; Huang, 2016; Kitchen, 2017; Lee et al., 2016); transport and accessibility (Borodako \& Rudnicki, 2014); destination brand and marketing (Ahn, Hyun et al., 2016; Kim \& Jun, 2016; Skinner, 2017).

\section{Destination competitiveness and site selection}

The growing attention that business tourism has received lately fosters the need to better understand how the tourism destinations have been working on this segment. Due to the increasing number of business events being held globally and the growing number of candidate cities to host the events, destination managers have to find new ways to increase competitiveness, especially through innovation and creation of complementary activities that enhance the overall business tourism experience (Colombo \& Marques, 2019). There seems to be a consensus regarding the importance of the overall tourism experience when it comes to business tourism and business events (Abulibdeh \& Zaidan, 2017; Ahn, Hyun et al., 2016; Alananzeh et al., 2019; Falk \& Hagsten, 2018; Skinner, 2017). It is important to pay attention not only to the specific destination attributes (e.g. conference venues, business hotels, transportation) but also to the complementary activities that the destination has to off er (leisure and recreation activities). In this context, Lichy and McLeay (2018) explored the new trend 'bleisure tourism' which means integrating leisure activities during a business trip. For Colombo and Marques (2019), the relationship between business and leisure can be even more specific through the combination of diff erent characteristics and activities in the same event, resulting in hybrid or symbiotic events (e.g. a trade fair that encompasses a music concert). Destinations should focus on the 'uniqueness' context of the business events (Colombo \& Marques, 2019) and provide memorable experiences to the business events attendees, enhancing the brand name recognition (Ahn, Hyun et al., 2016). The development of marketing policies by CVB (Lee et al., 2016) and more specifically, the network capacity and collaborative relationship of local stakeholders (Kitchen, 2017) are of strategic importance to foster the destination capacity and competitiveness. Nevertheless, other important aspects influence the selection of a business event destination. Crouch and Ritchie (1997), in their breakfront work about determinants for convention site selection identified the following determinant factors: accessibility, local support, extra-conference opportunities, accommodation facilities, meeting facilities, information and site environment, potential risks (related to possible strikes at destinations or natural disasters), profit opportunities, association image promotion (in case of association meetings) and destination novelty. Hankinson (2005) indicated eight clusters of brand images attributes from a business tourist perspective: physical environment, economic activity, business tourism facilities, accessibility, social facilities, reputation, people's characteristics and destination size. Particularly relevant for business tourism are functional attributes such as the quality and choice of conference and hotel facilities. Tsui et al. (2018) found two economic factors (economic policy uncertainty index and bilateral trade volumes) and two noneconomic factors (flying distance and total direct flight seats) as statistically determinants in explaining business 
tourism flows. More recently, Carvalho et al. (2018) identified what they called 'controllable' and 'uncontrollable' determinants of business tourism destinations. Under the uncontrollable factors, they pointed climate and natural disasters, natural environment, physical, cultural and linguistic distance, physical environment building (architecture, buildings and historical monuments), size of destination and cultural elements. As controllable determinants they identified monetary vacation costs, accessibility, accommodation and meeting equipment, country's information, dynamism of leisure tourism, urban, commercial and economic regeneration, security, opportunities for cultural and recreation activities, degree of financial and trade opening, dynamism of the industry, trade and services, hospitality facilities and local infrastructures. Finally, as recognized recently (Alananzeh et al., 2019), destination attractiveness and competitive advantages are important not only for business tourists (events attendees) but also for investors and buyers of business events such as associations, corporations and public organizations. Many of the business events determinants identified earlier can be found in the city of Porto which supports the need of a deeper reflexion to enhance business tourism development in the region.

\section{Methodology}

The overall aim of this study was to explore the potential to attract additional business tourism to Porto. The objectives were to promote a reflection among key stakeholders in the tourism sector in order to reach to a diagnosis of the business tourism segment and then propose a set of strategic measures to boost its development in the city.

\section{Research design}

Data were collected through a qualitative approach using a Delphi Technique. A qualitative analysis was chosen due to the exploratory character of the study. The intention was to extract from the respondents their thoughts freely said about the business tourism theme in Porto. In other words, a qualitative approach give rise to subjective aspects and reach spontaneously unconscious or even conscious motivation. The Delphi technique is a communication method based on the principle that decisions from a structured group of individuals are more accurate than those from unstructured groups (Rowe \& Wright, 2001). Indeed, the critical opinion of specialists or experts in a particular area is achieved in successive rounds until a consensus has been reached (Dalkey, 1969; Landeta, 2005). Participants are asked questions without coming into face-to-face contact with each other. Panel participants are not identified to each other during the course of the study and comments of the panellists are always included anonymously in each stage of the inquiry. This process has the advantage of elimination all interpersonal dynamics that tend to exist in face-to-face decision-making. In recent years, Delphi technique has been widely used in the tourism field (Lin \& Song, 2015).

\section{Participants}

The eligibility criteria of this study dictates that participants should, cumulative, meet the following requirements: (i) have professional or academic experience in the tourism sector 
and/or in the specific business tourism segment; (ii) develop their professional and/or academic activity in Porto and (iii) hold a vast knowledge of the city of Porto. After a careful research of the potential stakeholders that fulfilled the eligible criteria an invitation letter was send, by email, to each of the 55 stakeholders identified. Twenty-eight agreed to participate (final response rate of 51\%), thus constituting the initial panel. Participants in the panel were experts from seven diff erent areas, namely: four academics; four individuals from business and trade associations, four venues representatives; five accommodation and travel agents, four cultural, leisure and recreation suppliers, four individuals from public and institutional entities and three tourism managers. Their age ranged from 30 to 53 years old with a mean work experience of 18 years. There were 18 males and 10 females and all participants completed, at least, the higher education. Most of the experts $(85 \%)$ have never worked abroad but all reported attending often training activities in the tourism sector.

\section{Procedures and Delphi rounds}

The study involved three rounds of web-based questionnaires, all of them conducted by email and undertaken between September of 2018 and January of 2019. The questionnaire comprises two sections: A and B. The study here presented focused only in section A of the questionnaire. Therefore, only this description will be detailed. In round one, participants were asked five questions (one closed question and four open-ended questions) concerning the business tourism segment in the city of Porto. They were asked to identify: (i) whether they consider that there has been an adequate commitment, on the part of tourism authorities, on business tourism (closed question); (ii) the reasons why business tourism segment deserves special attention or the reason to assign more importance to business tourism in the city of Porto; (iii) measures related to venues facilities; (iv) required support services for business tourism; and (v) required investment in infrastructures. In round two, the lists of opinions/suggestions obtained from round one were compiled and organized. Participants were then asked to indicate on a five-point scale (not important, slightly important, important, significantly important and very important) the level of importance attached to each statement. Participants could also indicate additional items to the list. In round three, the final round, participants were faced with the results of the second round, were there was a tie in the answers. For these cases, participants were asked, once again, to indicate their level of agreement based on the same five-point scale.

It should be noted that the sample size decreased between rounds. From the first to the second round, two participants were missed (sample size 26). In the third round, one more respondent did not fulfil the questionnaire (final sample size 25).

\section{Findings and discussion}

\section{Awareness and strategic importance of business tourism in Porto}

When asked to express their options about business tourism development policies in Porto, most respondents (22) stated that tourism authorities have not given due attention to this segment. It reinforces the idea that local stakeholders know about the strategic 


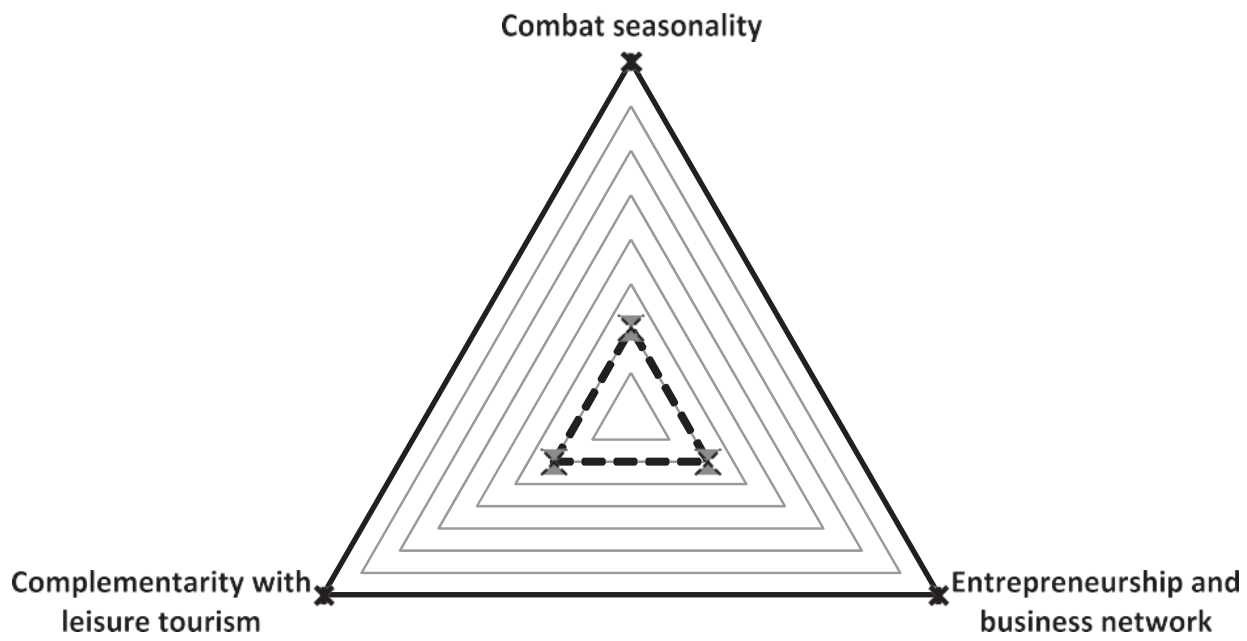

- $\rightarrow$ - Significantly important

$\longrightarrow$ Very important

Figure 1. Reasons to assign more importance to business tourism in Porto.

importance of business tourism but its potential has not been fully developed by local authorities and organizations. Experts were then asked to point out the main reasons why it should be given more attention to business tourism in Porto, presenting three main reasons, all of them considered equally important (Figure 1).

Respondents recognized that leisure tourism is mainly seasonal with tourism demand reaching its highest levels at very specific times of the year (especially in summer), leading to an intensive use of infrastructures, facilities and services for very limited periods of time. As business tourism can attract tourists in off -peak seasons, it is considered a strategic activity to reduce seasonality. Its importance is noted, especially, in hotel occupancy rates which, in periods of low season, depend largely on business tourism. Due to its complementary with leisure tourism, business tourism activity finds in leisure activities ways to enhance the overall tourism experience of those visiting a destination for business purposes. Thus, the business tourism experience in Porto can be value-added through visiting and touring activities (historical and cultural heritage; landscape and natural heritage), leisure and relaxing activities (thermal waters and spas) or complementary experiences (gastronomy and wines). All respondents recognized that Porto and the northern region of Portugal have important tourism assets that can enhance the business tourist experience. Experts also indicated the entrepreneurship and strong business network of the northern territory as one reason to justify the key role that should be attributed to business tourism segment especially in the corporate sector.

\section{The need to improve venue supply}

Concerning current venue supply in Porto, 19 participants indicated that there are still not enough venues for the development of business tourism. They were asked to propose 

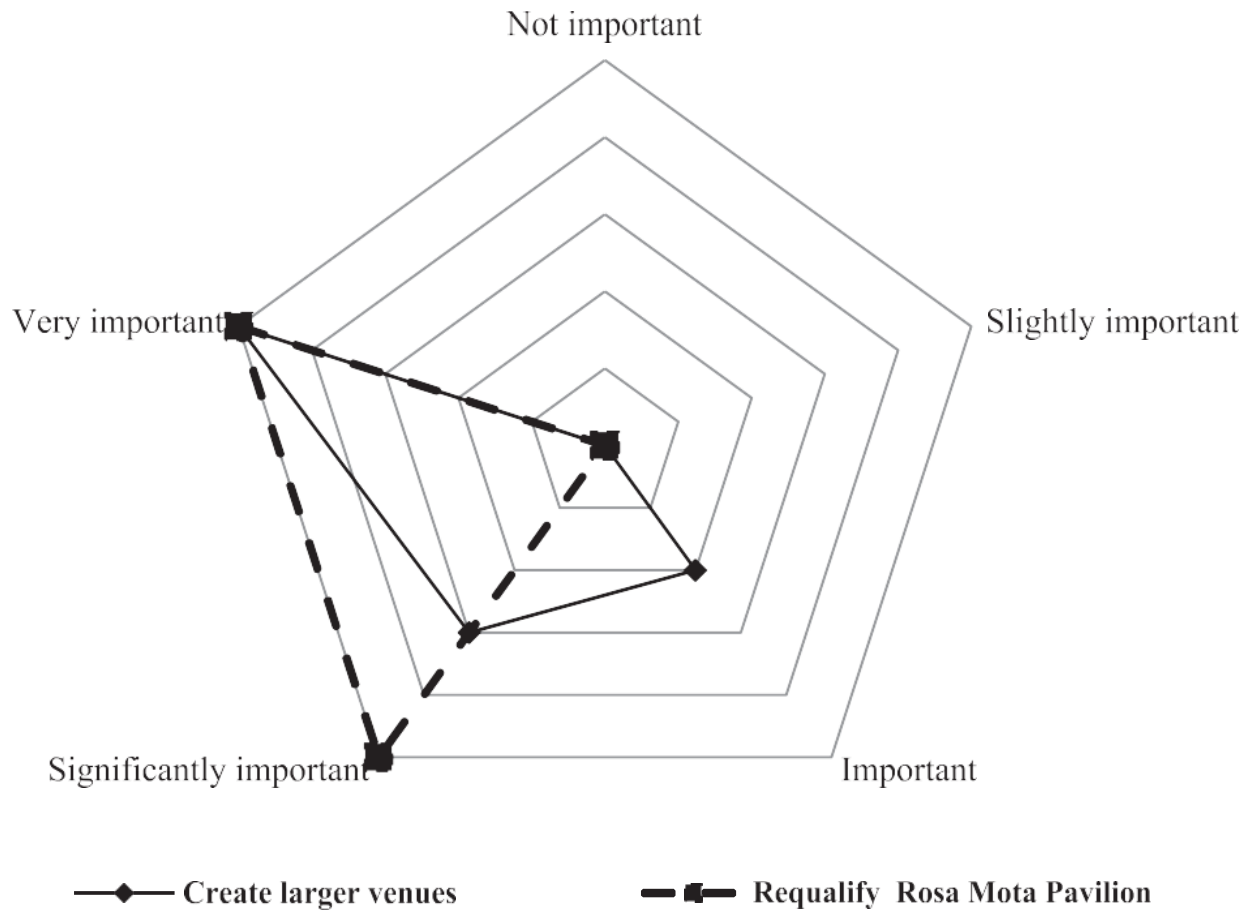

- T- Requalify Rosa Mota Pavilion

Figure 2. Venue facilities.

measures that should be developed in this context. Two main measures were indicated (Figure 2). First, the need to create a larger venue that allows Porto to compete in the national and international market by attracting larger conferences. Second, the need to requalify the existing Rosa Mota Pavilion. This renovation was very recently competed and the 'new' venue was reinaugurated (28th October 2019) and renamed as Super Bock Arena - Rosa Mota Pavilion.

\section{Improvement of specialized support services}

When asked about business tourism specialized support services, 17 participants considered that those services already exist in the city. Even so, some needs were pointed out (Figure 3).

The five indicated support services can be grouped into three areas of intervention (by increasing order of importance). The first (and considered as the most important) area of intervention consists in improving destination business events-related facilities and accessibilities. Respondents highlighted the importance of increasing venues supply and accessibility through more direct and regular flights to Porto. Providing more facilities was seen as a strategy to gain national and international competitiveness. The second intervention should be an improvement of promotion and sales of Porto as a business tourism destination. Experts reinforced the need to create a multidisciplinary sales team, suggesting the development of a professional organization exclusively dedicated to marketing and to attract international conferences. However, Porto already has a CVB whose purpose is, 


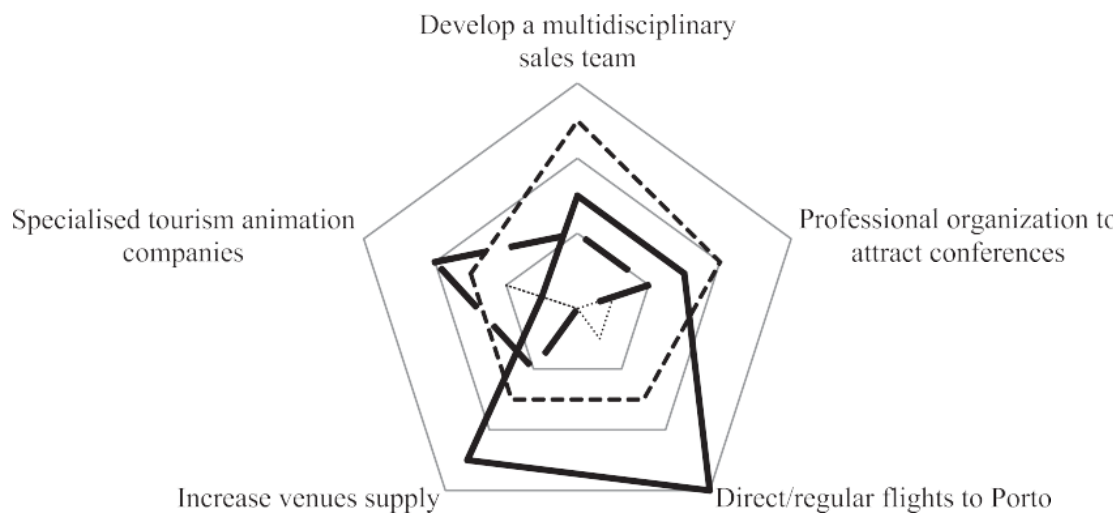

Slightly important

- Important

-----Significantly important

Very important

Figure 3. Required support services for business tourism.

precisely, to promote and implement marketing campaigns in an integrated way with local stakeholders. According to the perceptions revealed by experts it seems that the CVB needs to improve its performance to be recognized as effi cient by local stakeholders. The third area of intervention concerns local tourism animation companies. Not only venues, accommodation, food \& beverage and transport systems are important for business tourism in Porto. Leisure and tourism animation activities are also very important to increase destination attractiveness.

\section{Strategic investment in infrastructure}

When asked about the city infrastructures and if they are adequate for business tourism, half of the respondents believe so. Among those who think infrastructures are not enough, five development measures have been proposed (Figure 4).

From the measures indicated, the need for a new congress centre was unanimous. This result is consistent with previous findings (Figure 2). In both questions, experts realized that a new congress centre was very important to increase business tourism services and better qualify the supply of venues at destination. In this respect and following the pursuit of effi ciency, the strategy to be followed should be to take advantage of those that exist, requalifying them appropriately, as happened with the recent inauguration of the renovated Cyrstal Park (know renamed as Super Bock Arena - Rosa MotaPavilion). With this new off er, it is no longer necessary to build more congress centres of large size, especially not until those are properly monetized.

Increasing infrastructures to foster national and international connectivity was also pointed by participants as very important to business tourism. Increasing the rail network with the periphery was also rated as very important by participants, followed by the need to extent the subway network. This reinforces the importance of having good access and transport networks not only at the international context (airport) but also at local (metro) and regional (railway system) level. Finally, experts suggested 


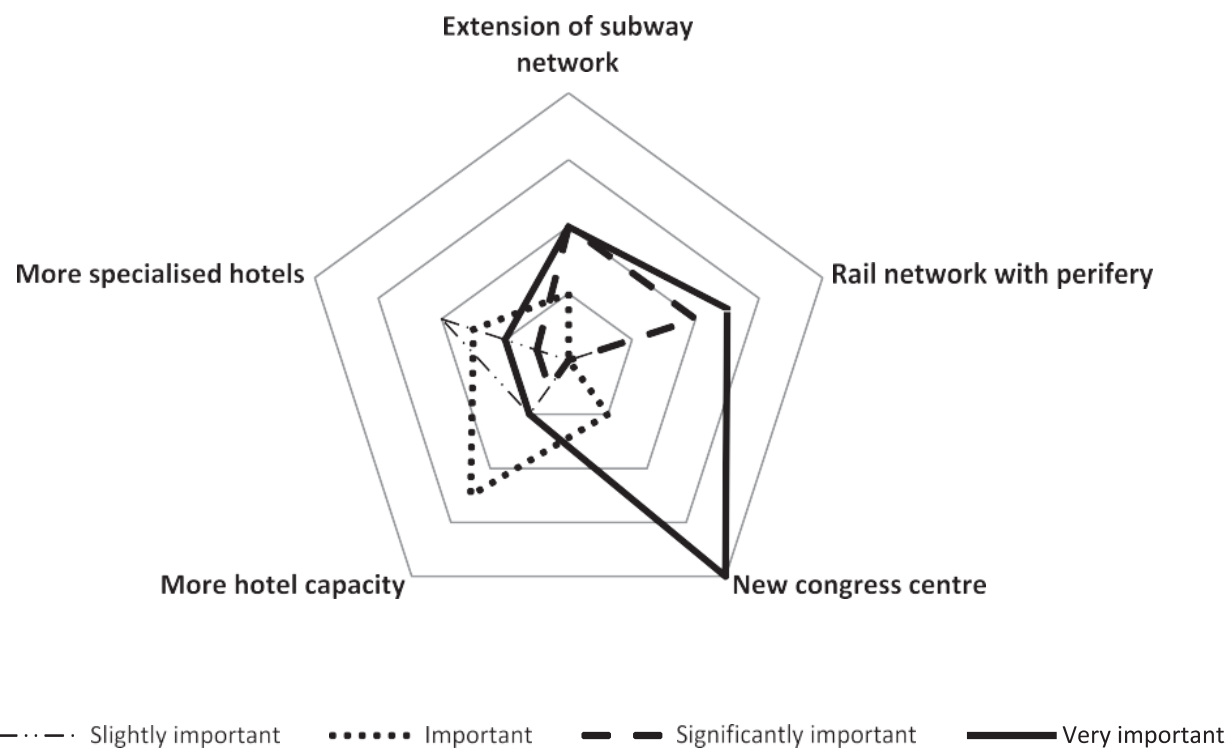

Figure 4. Required investment in infrastructures.

increasing hotel capacity. In recent years, significant investments have been made in this sector, especially at the level of 4 and 5 star hotels.

\section{Conclusions and final considerations}

This study reflects part of a wider project concerning the research of business tourism in the Northern region of Portugal and, more specifically, in the second largest country city - Porto. The main goal with this study was to diagnose Porto's business tourism segment and to propose a set of strategic measures to boost its development. The views of a group of local tourism stakeholders were collected through a Delphi technique. We found that stakeholders consider the business tourism segment very important to Porto not only to attract more tourists, especially in off -peak seasons, but also to promote entrepreneurship and business network. A number of improvements were proposed by respondents that would help build the brand of Porto as a business tourism destination of note as well as may provide guidance to all those directly involved in the business tourism segment around the world. These included more off er of large venues, collaborative cooperation between businesses in the area to develop and consolidate the sector, increase in the supply of animation, a stronger marketing strategy, building a cohesive brand, and increased accessibilities, connectivity and facilities.

These results are consistent with theoretical and empirical literature that indicate location and accessibility, conference facilities and service level, leisure activities and social facilities as critical factors behind choosing a destination (Carvalho et al., 2018; Crouch \& Louviere, 2004; Crouch and Ritchie (1997; Rogerson, 2015a, 2015b; Skinner, 2017; Zhang et al., 2007). 
This collaborative research with stakeholder's reflection proved to be important to identify strategies and policies to enhance business tourism at Porto city especially at a time when conference and event organizers seem to change their destination selection. Moreover, this study off ers constructive insights into strategies to develop business tourism worldwide and furthermore provide important implications for managers, policy makers and service providers. Typically, large or industrial cities were the main destinations for business events and business tourism. In recent years, the location and shape of business events has, however, significantly changed. More attention has been given to cultural and historical heritage attractions than to city's dimension (Falk \& Hagsten, 2018). In this context, Porto has a competitive advantage since the historic centre has been classified as a world heritage site by UNESCO. As stated by Crouch and Louviere (2004), traditional convention locations of some main large cities with more developed infrastructures have been losing market share to smaller cities and towns in more exotic locations with modern hi-tech meeting facilities. Thus, strategies of competition based mainly on accessibility, infrastructure and cost are not enough anymore. Destinations need to create a unique combination of attributes to develop strong competitive positions and must do so through an intimate knowledge of the factors that associations value most in their site choice decisions (Crouch \& Louviere, 2004). The widespread idea that associates business tourism to major urban centres with very large venues, accommodation and infrastructure seems to be outdated. Kim and Jun (2016) found that an unknown city could benefit more than a well-known city by improving the image of the city using event advertising as a promotional tool. Additionally, it has been evidenced, over the past years, a tendency to reduce the number of participants in associative meetings while the number of meetings held continues to increase. Therefore, the proposal put forward by participants regarding the need to invest in new and larger venues should be seen with caution even more as this involve high level of financial resource and high cost of maintenance which may jeopardize its sustainability. Instead of building new and larger congress centres, it will be more effi cient to requalify existing venues, which was actually the context of Super Bock Arena - Rosa MotaPavilion. This renewed venue has a great potential for Porto capacity improvement. Thereby, the overall services related to business tourism in general and to venue management in particular, airport logistics and hospitality management should be seen as more important strategic measures than the capacity level of destination to hold larger business events. To leverage this, the organizations responsible for the development of the business tourism in the city of Porto and tourism businesses need to work together. Unfortunately, there is no evidence that there is collaboration by businesses in the area to develop Porto as a business tourism destination. This should be a matter of concern and an urgent strategic measure to adopt - businesses working together to consolidate the business tourism sector and to develop and implement a focused business tourism message. It is crucial that CVB take eff ective action in promoting a cooperation between stakeholders and to pressure local, regional and national authorities to develop concerted policies and adequate branding strategies. Even through, there is currently some business tourism promotion in the northern territory of Portugal promoted by regional public tourism organization (Entidade Regional de Turismo Porto \& Norte de Portugal), regional tourism association (Associação de Turismo do Porto \& Norte de Portugal) and municipalities or municipal tourism 
companies. It is, however, yet necessary to structure this product in a more serious and collaborative way by including other services (venues, accommodation, catering, transport, tourist attractions, complementary activities, etc.) and the joint action of public and private agents.

One key strength of our study is its qualitative approach which allowed in-depth investigation of Porto's business tourism stakeholders concerns and suggestions to enhance the city as a business events destination by excellence. The results of the study should be, however, analysed with caution due to some methodology limitations. Although Delphi is considered a useful technique to collect qualitative data and to debate complex issues related to tourism planning and development, it is known that some Delphi's methodological issues remain unresolved, such as the definition of what constitutes a correct panel expert or the best way to present controlled feedback (Lin \& Song, 2015). Besides, the number of participants was small. However, it is believed that these drawbacks are overcome by the contribution of this study.

In follow-up research, it would be useful to develop more studies about the competitive factors for business tourism at national level, highlighting the characteristics of each region. Besides, it would be useful to use a larger sample and employ a mixed method study that comprises a qualitative and a quantitative analysis. It would also be interesting to explore the opinion of those who attend business events to draw a profile of this type of 'consumer'.

Overall, our findings suggest that business tourism stakeholders in Porto are aware of the key considerations that rationally lie in choosing a destination in order to enhance the event. They recognized as important commercial criteria conference facilities and service levels, location and accessibility, social facilities, activities and events. These criteria are an important factor in the decision-making process for destination selection. Additionally, our findings would give insights into the body of knowledge regarding strategies to develop business tourism segment and thus are of wider interest to all those directly involved with tourism.

\title{
Disclosure statement
}

No potential conflict of interest was reported by the author(s).

\section{ORCID}

\author{
Jorge Marques@ http://orcid.org/0000-0001-5392-5128 \\ Micaela Pinho http://orcid.org/0000-0003-2021-9141
}

\section{References}

Abulibdeh, A., \& Zaidan, E. (2017). Empirical analysis of the cross-cultural information searching and travel behavior of business travelers: A case study of MICE travelers to Qatar in the Middle East. Applied Geography, 85. https://doi.org/10.1016/j.apgeog.2017.06.001

Ahn, Y., Hyun, S., \& Kim, Y. (2016). City residents' perception of MICE city brand orientation and their brand citizenship behavior: A case study of Busan, South Korea. Asia Pacific Journal of Tourism Research, 21(3), 328-353. https://doi.org/10.1080/10941665.2015.1050422 
Ahn, Y., Kim, I., \& Lee, T. (2016). Exploring visitor brand citizenship behavior: The case of the 'MICE city Busan', South Korea. Journal of Destination Marketing \& Management, 5(3), 249259. https://doi.org/10.1016/j.jdmm.2016.01.002

Alananzeh, O., Al-Badarneh, M., Al-Mkhadmeh, A., \& Jawabreh, O. (2019). Factors influencing MICE tourism stakeholders' decision making: The case of Aqaba in Jordan. Journal of Convention E Event Tourism, 20(1), 24-43. https://doi.org/10.1080/15470148.2018.1526152

Almeida-García, F. (2018). Analysis of tourism policy in a developing country: The case of Morocco. Journal of Policy Research in Tourism, Leisure and Events, 10(1), 48-68. https://doi. org/10.1080/19407963.2017.1312420

Beni, M. (2001). Análise Estrutural do Turismo (6- ed.). Editora SENAC.

Boniface, B., \& Cooper, C. (2005). Worldwide destinations: The geography of travel and tourism (4a ed.). Elsevier.

Bornhorst, T., Ritchie, J., \& Sheehan, L. (2010). Determinants of tourism success for DMOs \& destinations: An empirical examination of stakeholders' perspectives. Tourism Management, 31(5), 572-589. https://doi.org/10.1016/j.tourman.2009.06.008

Borodako, K., \& Rudnicki, M. (2014). Transport accessibility in business travel - a case study of Central and East European cities. International Journal of Tourism Research, 16(2), 137-145. https://doi.org/10.1002/jtr.1908

Carvalho, P., Márquez, M., \& Díaz-Méndez, M. (2018). Policies to increase business tourism income: A dynamic panel data model. Journal of Convention E Event Tourism, 19(1), 63-82. https://doi.org/10.1080/15470148.2017.1380546

Cazanova, J., Ward, R., \& Holland, S. (2014). Habit persistence in air passenger traffi c destined for Florida. Journal of Travel Research, 53(5), 638-655. https://doi.org/10.1177/0047287513513173

Colombo, A., \& Marques, L. (2019). Motivation and experience in symbiotic events: An illustrative example grounded in culture and business events. Journal of Policy Research in Tourism, Leisure and Events, 1-17. https://doi.org/10.1080/19407963.2019.1657437

Crouch, G., \& Louviere, J. (2004). The determinants of convention site selection: A logistic choice model from experimental data. Journal of Travel Research, 43(2), 118-130. https://doi.org/10. $1177 / 0047287504268233$

Crouch, G., \& Ritchie, J. (1997). Convention site selection research: A review, conceptual model and propositional framework. Journal of Convention and Exhibition Management, 1(1), 49-69. https://doi.org/10.1300/J143v01n01_05

Dalkey, N. (1969). The Delphi method: An experimental study of group opinion. Rand Corporation.

Davidson, R. (2019). Business events (2nd ed.). Routledge.

Davidson, R., \& Cope, B. (2003). Business travel. Conferences, incentive travel, exhibitions, corporate hospitality and corporate travel. Pearson Education Limited.

Draper, J., Young Thomas, L., \& Fenich, G. (2018). Event management research over the past 12 years: What are the current trends in research methods, data collection, data analysis procedures, and event types? Journal of Convention \& Event Tourism, 19(1), 3-24. https://doi. org/10.1080/15470148.2017.1404533

ET. (2017). Estratégia Turismo 2027. Liderar o turismo do futuro. Ministério da Economia e da Inovação. Turismo de Portugal. Retrieved April 1, 2019, from https://estrategia. turismodeportugal.pt/sites/default/files/Estrategia_Turismo_Portugal_ET27_0.pdf

Falk, M., \& Hagsten, E. (2018). The art of attracting international conferences to European cities. Tourism Economics, 24(3), 337-351. https://doi.org/10.1177/1354816618758732

Getz, D., \& Page, S. (2016). Progress and prospects for event tourism research. Tourism Management, 52, 593-631. https://doi.org/10.1016/j.tourman.2015.03.007

Gustafson, P. (2012). Managing business travel: Developments and dilemmas in corporate travel management. Tourism Management, 33(2), 276-284. https://doi.org/10.1016/j.tourman.2011. 03.006

GWCRN. (2018). Globalization and World Cities Research Network. "The World According to GaWC 2018". https://www.lboro.ac.uk/gawc/world2018.html.

Hankinson, G. (2005). Destination brand images: A business tourism perspective. Journal of Services Marketing, 19(1), 24-32. https://doi.org/10.1108/08876040510579361 
Ho, G., \& McKercher, B. (2014). A Comparison of Long-Haul and short-Haul business tourists of Hong Kong. Asia Pacific Journal of Tourism Research, 19(3), 342-355. https://doi.org/10.1080/ 10941665.2012.746235

Huang, H. (2016). How does meetings, incentives, conventions, and exhibitions industry attract Exhibitors? Asia Pacific Journal of Tourism Research, 21(1), 73-93. https://doi.org/10.1080/ 10941665.2015.1016444

Iacuone, S., \& Zarrilli, L. (2018). Business tourism in China: The case of Guangzhou. GeoJournal of Tourism and Geosites, 23(3), 656-667. https://doi.org/10.30892/gtg.23303-317

ICCA. (2019). The international association meetings market 2016, ICCA Statistics Report - public

Abstract. Retrieved April 30, 2019, from https://www.iccaworld.org/dcps/doc.cfm?docid=2241

Jones, C., \& Li, S. (2015). The economic importance of meetings and conferences: A satellite account approach. Annals of Tourism Research, 52, 117-133. https://doi.org/10.1016/j.annals. 2015.03.004

Kim, S., \& Jun, J. (2016). The impact of event advertising on attitudes and visit intentions. Journal of Hospitality and Tourism Management, 29, 1-8. https://doi.org/10.1016/j.jhtm.2016.04.002

Kitchen, E. (2017). What is the value of networking? An examination of trade show attendee outcomes. Journal of Convention $\mathcal{E}$ Event Tourism, 18(3), 191-204. https://doi.org/10.1080/ 15470148.2017.1308285

Lage, B., \& Milone, P. (2000). Turismo: teoria e prática. Editora Atlas.

Landeta, J. (2005). El metodo Delphi (1 $\underline{\text { a }}$ ed. 1999). Ariel.

Lee, H., Lee, J., \& Jones, D. (2016). Exploring the interrelationship between Convention and Visitor Bureau (CVB) and its stakeholders, and CVB performance from the perspective of stakeholders. Journal of Travel \& Tourism Marketing, 33(2), 224-249. https://doi.org/10.1080/10548408.2015. 1050539

Lichy, J., \& McLeay, F. (2018). Bleisure: Motivations and typologies. Journal of Travel \& Tourism Marketing, 35(4), 517-530. https://doi.org/10.1080/10548408.2017.1364206

Lin, V., \& Song, H. (2015). A review of Delphi forecasting research in tourism. Current Issues in Tourism, 18(12), 1099-1131. https://doi.org/10.1080/13683500.2014.967187

Mair, J., \& Jago, L. (2010). The development of a conceptual model of greening in the business events tourism sector. Journal of Sustainable Tourism, 18(1), 77-94. https://doi.org/10.1080/ 09669580903291007

Millán, A., Fanjul, M. L., \& Moital, M. (2016). Segmenting the business traveler based on emotions, satisfaction and behavioral intention. Psychology E Marketing, 33(2), 82. https://doi.org/10.1002/ mar.20856

PENT. (2007). Plano Estratégico Nacional de Turismo para o desenvolvimento do turismo em Portugal. Ministério da Economia e da Inovação, Turismo de Portugal. Received January 10, 2019, from www.observatorio.pt/download.php?id=685

Rittichainuwat, B., \& Mair, J. (2012). An exploratory study of attendee perceptions of green meetings. Journal of Convention \& Event Tourism, 13(3), 147-158. https://doi.org/10.1080/15470148. 2012.706786

Rogers, T. (2008). Conferences and conventions. A global industry (2 $2^{\mathrm{a}}$ ed.). Butterworth-Heinemann.

Rogerson, C. (2015a). The uneven geography of business tourism in South Africa. South African Geographical Journal, 97(2), 183-202. https://doi.org/10.1080/03736245.2015.1028984

Rogerson, C. (2015b). Unpacking business tourism mobilities in sub-Saharan Africa. Current Issues in Tourism, 18(1), 44-56. https://doi.org/10.1080/13683500.2014.898619

Rowe, G., \& Wright, G. (2001). Expert opinions in forecasting: The role of the Delphi technique. In J. S. Armstrong (Ed.), Principles of forecasting (pp. 125-144). Springer. (International Series in Operations Research \& Management Science).

Skinner, H. (2017). Business tourists' perceptions of nation brands and capital city brands: A comparison between Dublin/Republic of Ireland, and Cardiff /Wales. Journal of Marketing Management, 33(9-10), 817-834. https://doi.org/10.1080/0267257X.2017.1313757

Swarbrooke, J., \& Horner, S. (2001). Business travel and tourism. Butterworth-Heinemann. 
Tan, D., \& Tsui, K. (2017). Investigating causality in international air freight and business travel: The case of Australia. Urban Studies, 54(5), 1178-1193. https://doi.org/10.1177/ 0042098015620520

Tsui, W., Balli, F., Tan, D. T. W., Lau, O., \& Hasan, M. (2018). New Zealand business tourism: Exploring the impact of economic policy uncertainties. Tourism Economics, 24(4), 386-417. https://doi.org/10.1177/1354816617731387

UNWTO. (2011). Tourism towards 2030: Global overview. Madrid: UNWTO.

Wang, Y., \& Beise-Zee, R. (2013). Preencounter aff ective states of business travelers and service responses. Journal of Hospitality Marketing $\mathcal{E}$ Management, 22(6), 634-655. https://doi.org/ 10.1080/19368623.2012.680243

Werner, K., Griese, K., \& Hogg, J. (2017). Service dominant logic as a new fundamental framework for analyzing event sustainability: A case study from the German meetings industry. Journal of Convention E Event Tourism, 18(4),318-343.https://doi.org/10.1080/15470148.2017.1365670

WTTC. (2018, March). World Travel E Tourism Council: Travel $\mathcal{E}$ Tourism Economic Impact 2018. https://www.wttc.org/-/media/files/reports/economic-impact-research/regions-2018/world2018. pdf

Zhang, H., Leung, V., \& Qu, H. (2007). A refined model of factors aff ecting convention participation decision-making. Tourism Management, 28(4), 1123-1127. https://doi.org/10.1016/j.tourman.

2006.07.008 